\title{
Influence of subcutaneous fat on mechanomyographic signals at three levels of voluntary effort
}

Eduardo Mendonça Scheeren*, Lindomar Mineiro, Eduardo Borba Neves, Eddy Krueger, Guilherme Nunes Nogueira Neto, Percy Nohama

\begin{abstract}
Introduction: This study aims to assess the influence of different skinfold thicknesses (ST) and their relation to the attenuation of the mechanomyographic (MMG) signal at different force levels (maximal voluntary contraction - MVC, $40 \%$ of MVC and $70 \%$ of MVC) of the rectus femoris muscle. Methods: Fifteen volunteers were divided in two groups: ST lower than $10 \mathrm{~mm}(\mathrm{G}<10)(8$ participants) and ST higher than $35 \mathrm{~mm}(\mathrm{G}>35)$ (7 participants). Student $t$ tests were employed to investigate differences between $\mathrm{G}<10$ and $\mathrm{G}>35$ regarding MMG analysis parameters (acceleration root mean square - aRMS, zero crossing - ZC, and median frequency - MDF), for the $\mathrm{X}, \mathrm{Y}$ and $\mathrm{Z}$ axes, as well as for the modulus of these three axes. Results: We found that thicker layers of body fat act as attenuator filters for the MMG signal [MDF $\mathrm{MVC}_{\mathrm{MC}}: \mathrm{X}(p=0.005), \mathrm{Z}(p=0.003)$; $\mathrm{MDF}_{70 \% \mathrm{MVC}}: \mathrm{X}(\mathrm{p}=0.034) ; \mathrm{ZC}_{\mathrm{MVC}}: \mathrm{Z}(p=0.037)$, modulus $\left.(p=0.005) ; \mathrm{ZC}_{70 \% \mathrm{MVC}}: \mathrm{Z}(p=0.047)\right]$. We found significant correlation between ST values and aRMS in three levels, in the $\mathrm{Y}_{\text {axis }}(p=0.591)$, for the group $\mathrm{G}<10$. For the modulus, the aRMS value showed correlation with $\mathrm{ST}$ values for group $\mathrm{G}>35$ in $40 \% \mathrm{MVC}$ $\left(\mathrm{R}^{2}=0.610\right)$, and $70 \% \mathrm{MVC}\left(\mathrm{R}^{2}=0.592\right)$. The MDF parameter showed correlation with ST values only in the $\mathrm{Y}_{\text {axis }}$ in $70 \% \mathrm{MVC}\left(\mathrm{R}^{2}=0.700\right)$ for $\mathrm{G}>35$. Conclusions: We observed MMG signal attenuation in at least one of the parameters analyzed for each level of the rectus femoris muscle force, indicating that MMG signals are significantly attenuated with increasing thickness of the subcutaneous fat layer.
\end{abstract}

Keywords: Mechanomyography, Skinfold, Signal attenuation, Level of force.

\section{Introduction}

Mechanomyography (MMG) is a noninvasive technique (Cramer et al., 2000) that records the vibrations or sounds produced by the lateral oscillations of muscle fibers upon contraction (Barry and Cole, 1990; Vaz and Herzog, 1999). These vibrations have low amplitude, are generated by muscle fiber contraction (Orizio, 1992; Youn and Kim, 2010) and consist of the signals transmitted by the recruited motor units (MU) (Yoshitake et al., 2002). The acquisition of the signals generated by muscle vibrations can be accomplished by means of piezoelectric acceleration transducers (Youn and Kim, 2010), which enable muscle analysis.

MMG is used in many applications, including: prostheses control (Orizio et al., 2003); indication of muscle activation degree (Scheeren et al., 2010); monitoring of muscle fatigue (Orizio et al., 2003; Tarata, 2003); neuromuscular diseases diagnosis (Hu et al., 2007); obtainment of signals for the study of muscle strength gradation mechanisms (Akataki et al., 2001; Matta et al., 2005; Madeleine et al., 2001; Nogueira-Neto et al., 2013); evaluation of respiratory muscle work (Sarlabous et al., 2014); changes in

*e-mail: eduardo.scheeren@pucpr.br

Received: 30 October 2015 / Accepted: 02 November 2016
MU activation strategies, which can occur with aging, neuromuscular diseases, endurance training programs, and care of injuries (Cooper et al., 2014); and Parkinson's disease (Marusiak et al., 2009; Malek and Coburn, 2012). In applications with comparisons between the MMG signal and the force response the biceps brachii (Orizio et al., 1989) and rectus femoris (Krueger et al., 2016; Shin et al., 2016) are the muscles more used due its easy accessibility and comparison capability.

However, signals generated by the muscle may suffer attenuation when propagated through tissues such as subcutaneous fat, thus hindering signal acquisition (Baars et al., 2007; Herda et al., 2010; Herda et al., 2011; Jaskólska et al., 2003; Yoshitake et al., 2002) and possibly attenuating signals as a low-pass filter (Cooper and Herda, 2014). Interferences in signal acquisition are found in studies that verified the influence of different skinfold thicknesses (ST) on the acquisition of MMG where the MMG signals were attenuated in muscles covered with high percentages of subcutaneous fat (Cooper et al., 2014; Herda et al., 2010; Herda et al., 2011; Trevino and Herda, 2015). 
For example, Cooper et al. (2014) observed correlations $(p<0.05)$ between skinfold thicknesses and MMG signal for the muscles rectus femoris and vastus lateralis with $\mathrm{r}=-0.376$ and -0.484 , respectively. Similarly, the amplitude of electromyography (EMG) and MMG signals showed a reduction in the entire force spectrum in muscles with greater ST during progressive isometric muscle actions (Cooper et al., 2013; Herda et al., 2010; Herda et al., 2011). Herda et al. (2010) observed differences when smaller and larger ST were related in progressive isometry using linear regression for $\mathrm{MMG}_{\mathrm{RMS}}$ vs. force relationships. In their study, those who trained endurance had smaller ST than the sedentary ones, in which the ST appear to have acted as a low-pass filter, supporting the work of Jaskólska et al. (2003), which confirmed the hypothesis of fat acting as a low-pass filter after correlating ST with age and isometric strength.

Studies with different force levels (Cochrane et al., 2015; Cooper et al., 2014; Jaskólska et al., 2003; Polato et al., 2008) reported significant differences when evaluating different intensities of isometric force with ST in larger and smaller fat layers. However, those researchers did not show if there is a trend related to different force levels or if this influence occurs in all (three) accelerometers axes. With the force increase, new motor units located in different places of the muscle are recruited influencing the vibration pattern of each axis (Herda et al., 2010) once the amplitude of MMG for the rectus femoris muscle contraction represents a mechanical 3-axis signal (Shin et al., 2016) and it is generated by the motor units coherence increasing the mechanical wave amplitude (Krueger et al., 2016).

However, we did not identify a systematic study to evaluate the influence of different ST using an experimental protocol with different levels of force by triaxial accelerometry. It makes us wonder whether the temporal and spectral indicators are sensitive to the ST influence considering the increased vibration of motor units at different force levels.

We hypothesize that the MMG signal suffers attenuation according to the thickness of the subcutaneous fat layer independently of its force level. Thus, the aim of this study was to assess the influence of different ST and their relation to the attenuation of the MMG signal at different force levels of the muscle rectus femoris.

\section{Methods}

\section{Participants}

Fifteen male volunteers (age: $24.47 \pm 2.57$ years, height: $1.72 \pm 0.05 \mathrm{~m}$, body weight: $77 \pm 16.2 \mathrm{~kg}$ ) participated in this study. They were intentionally divided in two groups: ST lower than $10 \mathrm{~mm}(\mathrm{G}<10)$ $(\mathrm{n}=8$ volunteers $)$ and ST greater than $35 \mathrm{~mm}(\mathrm{G}>35)$ $(\mathrm{n}=7$ volunteers). All subjects were healthy and had no history of neuromuscular disorders or musculoskeletal injuries. We selected those two skinfold thickness bands to ensure real differences in subcutaneous fat layer between groups and to avoid intra-evaluator measurement variability.

The experimental protocol of this study was approved by the Ethics Committee for Human Research of the Pontifical Catholic University of Paraná (PUCPR) under the approval No. 490.521/13. All subjects were informed about the steps and procedures to be performed during the research, and signed the Informed Consent Form after agreeing to participate in the study.

\section{Research design}

First, asepsis and shaving were performed at the medial point of the dominant thigh (muscle rectus femoris belly) for positioning of the MMG Although the difference, and at the same point three measurements of ST were carried out using an adipometer $\left(\right.$ Lang $\left.^{\circledR}\right)$ for estimation of localized fat (Cooper and Herda, 2014). Three submaximal contractions were performed as located warm-up, as well as stretching of the lower muscle group (quadriceps) 5 min prior to the beginning of the tests (Baptista et al., 2009). A load cell $(100 \mathrm{~kg}, 2.0 \pm 0.1 \mathrm{mV} / \mathrm{V}$, EMG System do Brasil $^{\circledR}$ ) was used to obtain the force in the knee extensor muscles.

\section{Protocol}

The participants were seated and secured by the pelvis with retention straps in a knee extension chair with an affixed load cell, with the knee positioned at $60^{\circ}$ extension $\left(0^{\circ}\right.$ corresponding to the complete extension) (Figure 1). Isometric contraction was employed to measure the force (Neering et al., 1991; Akataki et al., 1996; Akataki et al., 2001; Alves and Chau, 2008; Krueger et al., 2013).

The volunteers performed three maximal voluntary contractions (MVC) of $5 \mathrm{~s}$ with 5 min interval between them to avoid possible effects of fatigue (Correa et al., 2011; Gonçalves and Barbosa, 2005). Verbal encouragement was given in all trials (Baptista et al., 2009), and the highest value obtained was used as reference to define the submaximal values of $40 \%$ of MVC and $70 \%$ of MVC. The protocol sequence was (i) $\mathrm{MVC}$, (ii) $40 \%$ of MVC and (iii) $70 \%$ of MVC. It was chosen to start the submaximal protocol at $40 \%$ of MVC to ensure a fresh muscle condition for the $70 \%$ of MVC in the next test. To perform the submaximal contractions ( $40 \%$ and $70 \%$ ), reference 
lines (thresholds) were indicated on the monitor screen placed in front of the participant so they could be viewed and thus the voluntary contractions could be kept for $5 \mathrm{~s}$ in the determined threshold $(40 \%$ or 70\%) (Krueger et al., 2013).

\section{Mechanomyography}

The rectus femoris muscle shape is bipennate (Blemker and Delp, 2006), thus, it can cause tridimensional displacement during contraction. Therefore, the MMG system employed in the study has a triaxial sensor MEMS MMA7260Q (Freescale Semiconductor Corporation) with sensibility of $800 \mathrm{mV} / \mathrm{G}$ (G: gravitational acceleration) for acquisition of the MMG signal in the $Y_{\text {axis }}$ (longitudinal), $X_{\text {axis }}$ (transversal), and $Z_{\text {axis }}$ (perpendicular) of the rectus femoris muscle (Figure 1). All signals were obtained by a computing system consisting of a software developed in the LabVIEW platform and a hardware (MMG device and MMG sensor). The signal was acquired by an acquisition board from Data Translation ${ }^{\mathrm{TM}}$ (series DT300) with sampling rate of $1 \mathrm{kHz}$. The collected signals of each participant were stored in data digital files called EDF (Kemp and Olivan, 2003). Double-sided tape was used to affix the MMG sensor on the skin, on the rectus femoris muscle belly. A noninverting amplifier circuit was built and adjusted to provide a 10x gain and the output signal was sent to $4-40 \mathrm{~Hz}$ band-pass (Butterworth) filtering circuit (Krueger et al., 2013; Perry et al., 2001).

\section{Data analysis}

The data were processed by the Matlab ${ }^{\mathrm{TM}}$ (MathWorks) program version 8.2. For all force levels, the analysis window was $1 \mathrm{~s}$ (Nogueira-Neto et al.,

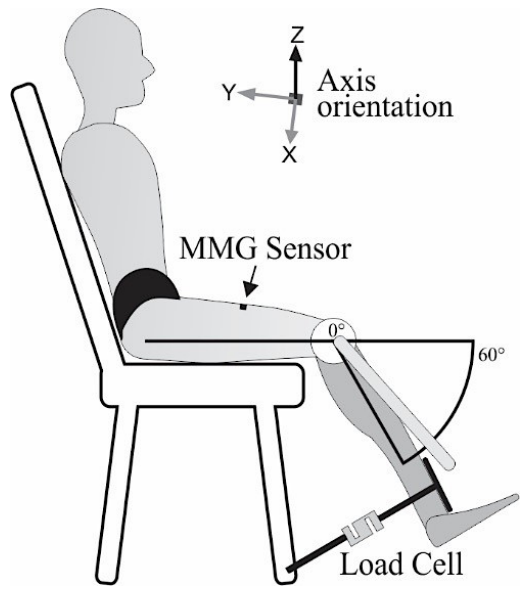

Figure 1. Knee extension chair with affixed load cell and positioning of the MMG sensor centrally at the mid-thigh (50\% of the length) and the axes orientation (z: vertical axis; y: antero-posterior axis; $\mathrm{x}$ : medio-lateral axis).
2013). The MMG sensor has three axes and each one provides data of muscle vibrations in one of three orthogonal directions. The most minimalist way of monitoring muscle vibration might involve acquiring signals from a single axis normal to the skin surface. However, such monitoring would not register vibrations in directions different from those of the normal axis. Since the transducer embedded in the MMG sensor is a triaxial accelerometer, muscle vibration data can be acquired in three orthogonal directions (X, $\mathrm{Y}$, and $\mathrm{Z}$ ). The modulus can be computed from the individual data of each axis, as stated in (1).

$$
\text { Modulus }^{2}=\left(M M G_{x}^{2}+M M G_{y}^{2}+M M G_{z}^{2}\right)
$$

For the three axes (X, Y, and $\mathrm{Z}$ ) and modulus during MVC performance, the analysis window of the MMG signal was determined by the instant at which the force peak occurred, which was centered in the window, dividing it into two equal parts of $0.5 \mathrm{~s}$ (Bassani et al., 2008; Nogueira-Neto et al., 2010).

To analyze the MMG signals, numerical parameters of temporal features, acceleration root mean square (aRMS), and number of crossings by the zero crossing $-\mathrm{ZC}$ (the baseline or system reference) were used. Youn and Kim (2010) indicate ZC to quantify frequency, and it can also be used as indication of the power and spectral changes in the signals. For frequency domain, the median frequency (MDF) was the analyzed parameter (Nogueira-Neto et al., 2010).

\section{Statistical analysis}

The statistical procedures were performed using the application program SPSS ${ }^{\circledR}$ Statistics version 20. The Shapiro-Wilk test was used to verify whether the distribution of the variables approached the Gaussian distribution. The analysis of variance (two-way ANOVA) was not performed once the interaction effect was observed, then the Student $t$ test for independent samples was applied to analyze possible differences between the groups $\mathrm{G}<10$ and $\mathrm{G}>35$ regarding force, MMG analysis parameters (aRMS, ZC, and MDF), for the axes (X, Y, and $\mathrm{Z}$ ), and the modulus of the three axes. A significance level of $95 \%(p<0.05)$ was adopted in all hypotheses tests.

\section{Results}

The force response at the intensity MVC between groups indicate that $\mathrm{G}>35$ has higher values than $\mathrm{G}<10$ (Table 1). The results obtained with $t$ test for independent samples, between the $\mathrm{G}<10$ and $\mathrm{G}>35$ groups with the aRMS parameter (Figure 2) and at the intensities $\mathrm{MVC}, 40 \% \mathrm{MVC}$, and $70 \% \mathrm{MVC}$ did not show any significant data for individual axes or the modulus. 
Regarding the ZC parameter (Figure 3), the $t$ test showed statistical significance for the $\mathrm{Z}_{\text {axis }}$, in $\mathrm{MVC}$ $(\mathrm{p}=0.037)$ and $70 \% \operatorname{MVC}(p=0.047)$, whereas for the modulus there was significance only in $70 \% \mathrm{MVC}$ $(p=0.035)$. For the MDF parameter (Figure 4), the $t$ test for independent samples showed significant values for $\mathrm{X}_{\text {axis }}$ in $\operatorname{MVC}(p=0.005)$ and in the $70 \%$

Table 1. Mean and standard deviation of force $(\mathrm{N})$ between the groups $\mathrm{G}<10$ and $\mathrm{G}>35$. Differences between groups are indicated by $p$-value.

\begin{tabular}{crc}
\hline & \multicolumn{1}{c}{ Force $(\mathbf{N})$} & $\boldsymbol{p}$-value \\
\hline $\mathrm{G}<10$ & $86.3 \pm 16.1$ & 0.013 \\
$\mathrm{G}>35$ & $107.4 \pm 16.9$ & \\
\hline
\end{tabular}

MVC intensity $(p=0.034) . Y_{\text {axis }}$ presented significant values $(p=0.013)$ in the MVC intensity as well as $\mathrm{Z}_{\text {axis }}(p=0.003)$. The modulus showed difference only in $\operatorname{MVC}(p=0.005)$.

We found a significant correlation between ST values and aRMS only in MVC, in the $\mathrm{Y}_{\text {axis }}(\mathrm{p}=0.591)$, for the group $\mathrm{G}<10$. For the modulus, the aRMS value showed correlation with $\mathrm{ST}$ values for group $\mathrm{G}>35$ in $40 \% \mathrm{MVC}\left(\mathrm{R}^{2}=0.610\right)$, and $70 \% \mathrm{MVC}\left(\mathrm{R}^{2}=0.592\right)$ (Figure 5).

The linear correlation obtained between $\mathrm{G}<10$ and $\mathrm{G}>35$ (Figure 6) with the $\mathrm{ZC}$ parameter and $\mathrm{ST}$ values showed significance only in $\mathrm{Y}_{\text {axis }}$ and
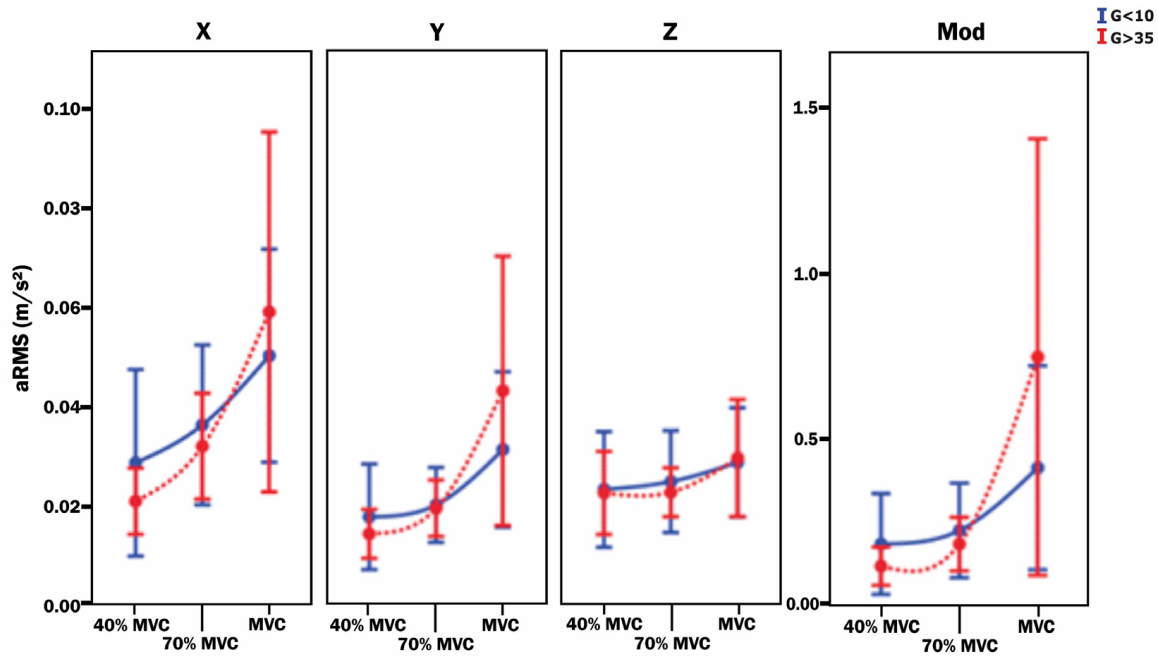

Figure 2. Mean and standard deviation of $\mathrm{MMG}_{\text {aRMS }}$ values of the mechanomyographic signal between groups $\mathrm{G}<10$ and $\mathrm{G}>35$, correlated with the MMG signals and respective axes, of the rectus femoris muscle and its modulus (z: vertical axis; $y$ : antero-posterior axis; $x$ : mediolateral axis).
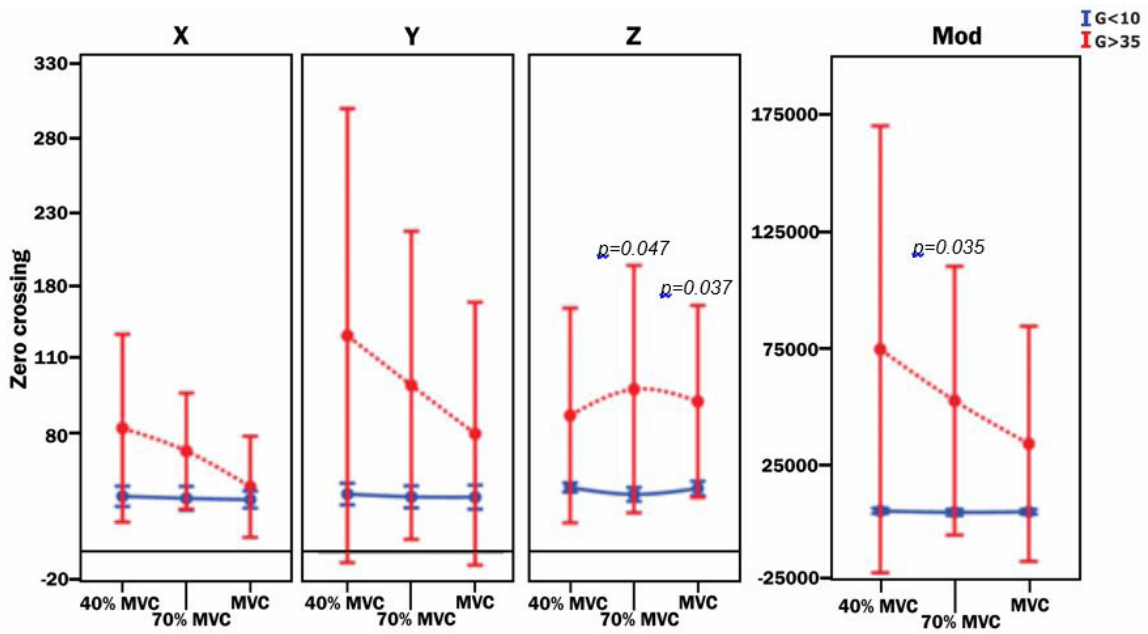

Figure 3. Mean and standard deviation of the zero crossing values of the mechanomyographic signal between groups $\mathrm{G}<10$ and $\mathrm{G}>35$, correlated with the MMG signals and respective axes, of the rectus femoris muscle and its modulus (z: vertical axis; y: antero-posterior axis; $\mathrm{x}$ : medio-lateral axis). Difference between groups are indicated by $p$-value. 
during MVC $\left(\mathrm{R}^{2}=0.663\right)$. In the analysis of the modulus, ZC showed correlation only in $70 \% \mathrm{MVC}$ $\left(\mathrm{R}^{2}=0.445\right)$.
The MDF parameter showed correlation with ST values only in $\mathrm{Y}_{\text {axis }}$ in $70 \% \mathrm{MVC}\left(\mathrm{R}^{2}=0.700\right)$ for $\mathrm{G}>35$ (Figure 7). We noticed the same for modulus
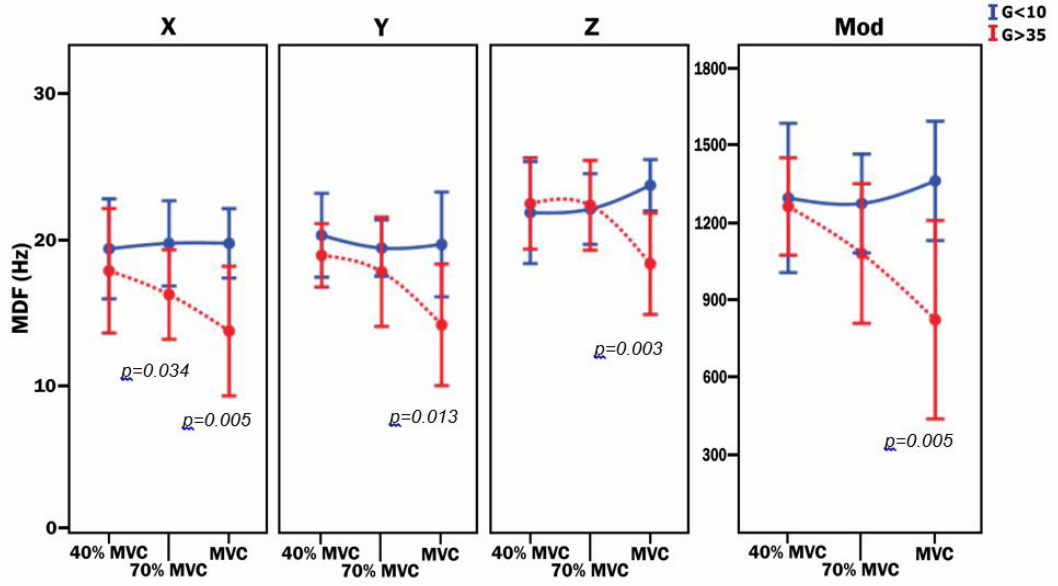

Figure 4. Mean and standard deviation of the MDF values of the mechanomyographic signal between groups $\mathrm{G}<10$ and $\mathrm{G}>35$, correlated with the MMG signals and respective axes, of the rectus femoris muscle and its modulus (z: vertical axis; y: antero-posterior axis; $\mathrm{x}$ : medio-lateral axis). Difference between groups are indicated by $p$-value

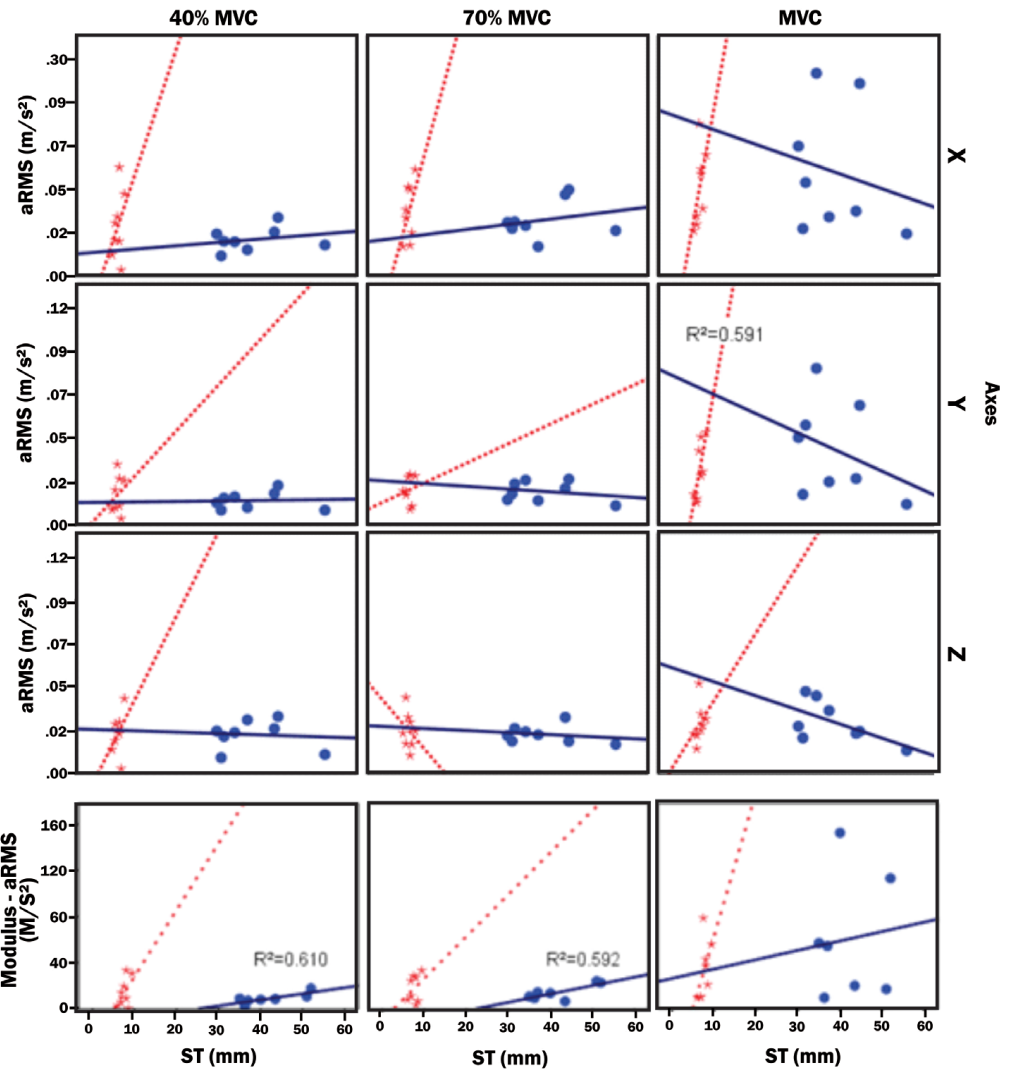

Figure 5. Correlation between the $\mathrm{ST}$ values and $\mathrm{MMG}_{\mathrm{aRMS}}$ parameter between groups $\mathrm{G}<10$ and $\mathrm{G}>35$ for the magnitudes $\mathrm{MVC}, 40 \% \mathrm{MVC}$, and $70 \% \mathrm{MVC}$ in the axes $\mathrm{X}, \mathrm{Y}$, and $\mathrm{Z}$ of the rectus femoris muscle and modulus of the respective axes and magnitudes, in which $\mathrm{R}^{2}$ corresponds to the variables correlation magnitude. 


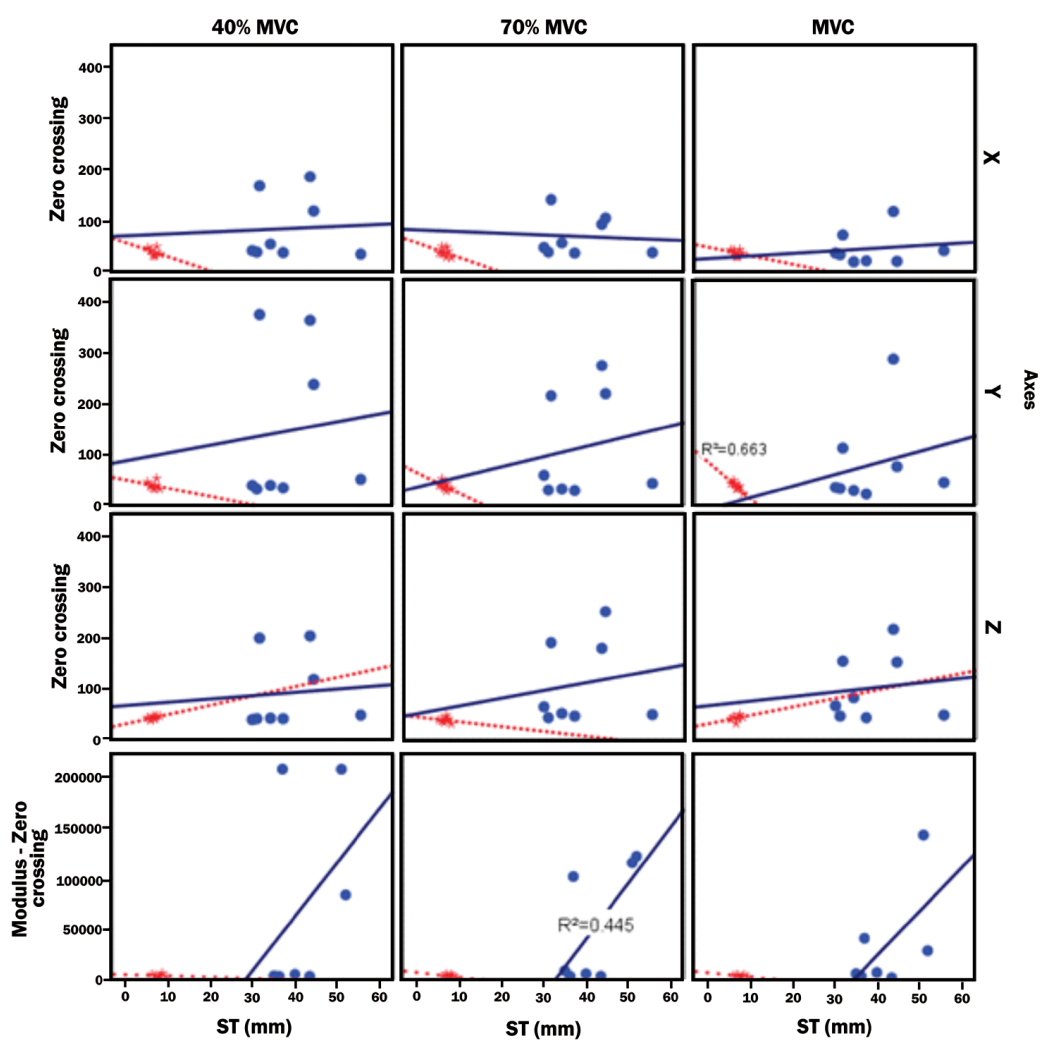

Figure 6. Correlation between the ST values and the $\mathrm{ZC}$ parameter of the mechanomyographic signal between groups $\mathrm{G}<10$ and $\mathrm{G}>35$ for the magnitudes MVC, $40 \% \mathrm{MVC}$, and $70 \% \mathrm{MVC}$ in the axes $\mathrm{X}, \mathrm{Y}$, and $\mathrm{Z}$ of the rectus femoris muscle and modulus of the respective axes and magnitudes, in which $\mathrm{R}^{2}$ corresponds to the variables correlation magnitude.

that showed correlation only in $70 \% \mathrm{MVC}$ for $\mathrm{G}>35$ (Figure 7).

\section{Discussion}

The amplitude of the signal generated by the skeletal muscle may be influenced by factors such as number of recruited motor units (MU) (Akataki et al., 2004; Herda and Cooper, 2015), firing rates of the active MUs (Orizio et al., 2003), distance between MUs and sensors (MMG), electrodes (EMG) (Barkhaus and Nandedkar, 1994), and interference of elements such as skin, liquids, and subcutaneous fat (Jaskólska et al., 2003). These events are widely reported in the literature, especially in studies with EMG (Barkhaus and Nandedkar, 1994; Marusiak et al., 2009). However, subcutaneous fat may also affect procedures conducted using MMG, although the origins of each signal are of different natures (EMG electrical signal and $M M G$ mechanical signal) (Krueger et al., 2013).

For this study, the MMG aRMS temporal reference values of groups $\mathrm{G}<10$ and $\mathrm{G}>35$ obtained from the rectus femoris muscle had no statistical difference
(Figure 2). Different results were found by da Matta et al. (2005), who obtained, for the aRMS parameter in $X_{\text {axis, }}$, greater values only for the male group, with women showing lower rates of MU activation. They used a biaxial sensor for the acquisition of MMG signals during voluntary contractions of the brachial biceps muscle of men and women at different levels of isometric force. The authors attributed this fact to the thicker layers of body fat found in the female group, which may have attenuated the MMG signal (da Matta et al., 2005), however the methods used as MMG sensor (bi vs. triaxial), muscle location (upper vs. lower limb) and gender (female vs. male) can be possible sources of differences found between their methods with ours.

Linear regression demonstrated, for $\mathrm{G}<10$ and $\mathrm{G}>35$ and in relation to the MMG signal and the aRMS parameter (Figure 5), that only in the MVC intensity, in $\mathrm{Y}_{\text {axis }}$, there was moderate linear regression for the $\mathrm{G}<10$ group $\left(\mathrm{R}^{2}=0.591\right)$. For the modulus we verified that in $40 \% \mathrm{MVC}\left(\mathrm{R}^{2}=0.610\right)$ and $70 \% \mathrm{MVC}$ $\left(\mathrm{R}^{2}=0.592\right)$ there was correlation $(0.610$ and 0.592 , respectively) for group $\mathrm{G}>35$ (Figure 5). For this study, 


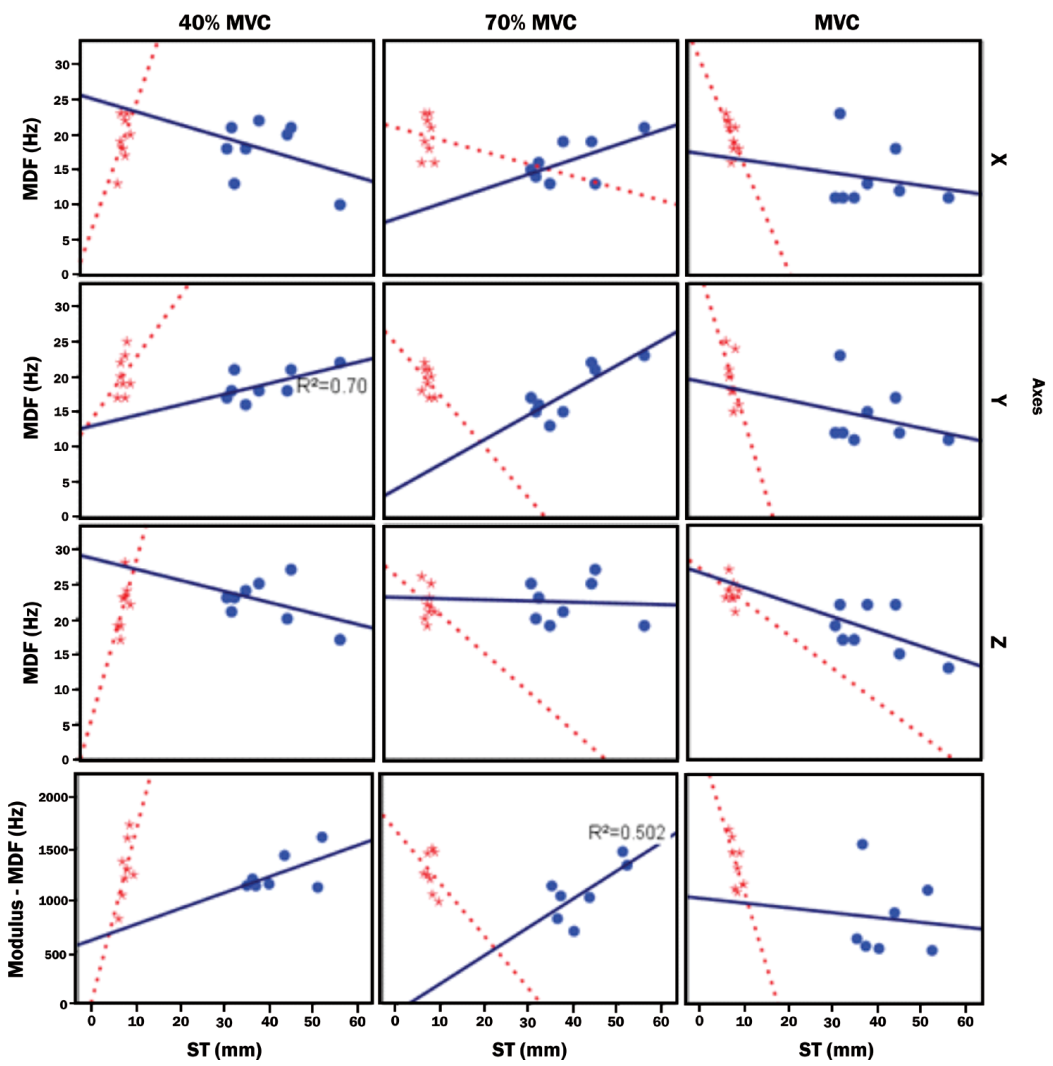

Figure 7. Correlation between the $\mathrm{ST}$ values and the MDF parameter of the mechanomyographic signal between groups $\mathrm{G}<10$ and $\mathrm{G}>35$ for the magnitudes $\mathrm{MVC}, 40 \% \mathrm{MVC}$, and $70 \% \mathrm{MVC}$ in $\mathrm{X}$, $\mathrm{Y}$, and $\mathrm{Z}$ axes of the rectus femoris muscle (A) and modulus of the respective axes and magnitudes (B); in which $\mathrm{R}^{2}$ corresponds to the variables correlation magnitude.

when the groups were analyzed separately (Figure 5), it was possible to observe that only group $\mathrm{G}<10$ has variation and only in one axis; the modulus, on the other hand, has differences for the group with greater levels of ST, G>35 (Figure 5).

The results of this study are similar to those of Krueger et al. (2013), who analyzed the influence of different ST on MMG signal of rectus femoris muscle during $\mathrm{MVC}$, and found that thicker layers of fat act as a low-pass filter to the MMG signal as sensed by the aRMS value, i.e. they attenuate the MMG signal. The authors evaluated two groups, $\mathrm{G}<10(\mathrm{~N}=10)$ and $\mathrm{G}>30(\mathrm{~N}=2)$ using a similar methodology that in present study. They found aRMS lower values to $\mathrm{G}>30$ than $\mathrm{G}<10$ at $\mathrm{Z}(1.3 \pm 0.4$ and $2.7 \pm 0.8 \mathrm{Vrms})$ and modulus axes $(2.7 \pm 0.4$ and $5.8 \pm 1.8 \mathrm{Vrms})$. According to Orizio et al. (1989), these attenuations are indications that the body fat served as a low-pass filter for the MMG signals of the analyzed muscle. These findings corroborate with those of Herda et al. (2010), who also analyzed the MMG and EMG signals, observing the aRMS values of aerobically trained (ST $8.7 \mathrm{~mm}$ ), resistance-trained (ST $15.4 \mathrm{~mm}$ ), and sedentary (ST $25.4 \mathrm{~mm}$ ) individuals, in progressive isometric contraction tests (5-90\% of MVC).

Similarly, Cooper and Herda (2014) observed that fat acts as a low-pass filter, with the $\mathrm{MMG}_{\text {aRMS }}$ value of the first dorsal interosseous muscle (ST $4.00 \pm 0.65 \mathrm{~mm}$ ), vastus lateralis muscle (ST $9.68 \pm 3.61 \mathrm{~mm}$ ) and rectus femoris muscle (ST $11.33 \pm 4.1 \mathrm{~mm}$ ) in progressive force test. These findings disagree with those of Beck et al. (2004), who observed that, as force increased, an increase was also obtained in the linear regression $\left(\mathrm{R}^{2}=0.984\right)$ of the MMG signal for the force peak of the brachial biceps muscle of 6 men and 6 women, during isokinetic contraction. In fatigue condition, Zuniga et al. (2010) found, for a homogenous group, that the STs did not interfere in the characteristics of the MMG signals, for both spectral and temporal aspects.

The ZC parameter showed significant differences between groups $\mathrm{G}<10$ and $\mathrm{G}>35$ by independent $t$ test. This occurred for the MMG signal in $Z_{\text {axis }}(p=0.037)$ in MVC and also ( $p=0.047)$ in 70\% MVC (Figure 4) and modulus (Figure 3 ) for MVC ( $p=0.005)$. 
The ZC parameter between the groups showed correlation for group $\mathrm{G}<10\left(\mathrm{R}^{2}=0.663\right)$ in the MVC intensity in $Y_{\text {axis }}$ (Figure 6) and for group $G>35$ $\left(\mathrm{R}^{2}=0.445\right)$ in modulus (Figure 6).

Different results were found by Krueger et al. (2013), who correlated different ST with the $\mathrm{ZC}$ value and found very low linear regression $(p=0.02)$ only for $Z_{\text {axis }}$. The results indicate that body fat acts as a low-pass filter, since the decrease in the $\mathrm{ZC}$ value can be interpreted as a decrease in the frequency of muscular mechanical vibration.

According to the protocol developed in this study, in which 5 min-intervals were performed to avoid possible effects of fatigue, the attenuation of signal by increased subcutaneous fat did not occur due to the reduction of vibration of the MUs, but in the impossibility of acquiring all muscular vibration frequencies, even in maximum contractions. Fat thickness seems to acts as a filter, which attenuates high-frequency components. This phenomenon can be observed in Figure 8, which shows the signal of two representative participants of the groups $(\mathrm{G}<10$ and $\mathrm{G}>35)$. For $\mathrm{G}>35$, as shown in Figure 8, there is a spectral compression for low frequencies.

According to Nogueira-Neto et al. (2013), ZC is only a valid indicator to describe force behavior during a fatigue protocol and not for muscular contraction behavior. Concerning the frequency domain (MDF) between the two groups with independent $t$ test, we found significant data (Figure 4) in the MVC magnitude in $\mathrm{X}_{\text {axis }}(p=0.005)$ and in $70 \%$ magnitude also in $\mathrm{X}_{\text {axis }}$ $(p=0.034) . \mathrm{Y}_{\text {axis }}$ had statistical significance in the MVC magnitude $(p=0.013)$, as well as $Z_{\text {axis }}(p=0.003)$.

In Figure 7, linear regression can be observed for $\mathrm{Y}_{\text {axis }}$ in $70 \% \mathrm{MVC}$ for $\mathrm{G}>35\left(\mathrm{R}^{2}=0.700\right)$ and modulus linear regression (Figure 7) for 70\% MVC
$\left(\mathrm{R}^{2}=0.502\right)$. Such results corroborate the study by Polato et al. (2008), which used a biaxial sensor to evaluate the relation between the behavior of the MMG signal and median frequency (MDF) of the brachial biceps muscle in different levels of isometric contraction $(20 \%, 40 \%, 60 \%, 80 \%$, and $100 \% \mathrm{MVC})$ of male and female individuals. Polato et al. (2008) associated the decrease in MMG signal of the women to the fact that the subcutaneous fat layer of these groups is thicker, which is similar to the results of da Matta et al. (2005). According to Krueger et al. (2013), when MDF and ST were analyzed, indication that the fat tissue worked as a low-pass filter for the rectus femoris muscle MMG signals was found for axes $\mathrm{X}$ and $\mathrm{Y}$. Also corroborating these findings, Jaskólska et al. (2003) observed that the correlation with ST and MDF in antagonist action of the brachial triceps muscle with greater ST indicated attenuation of the signals, between muscle and skin surface, independently of the individuals' age.

The facts presented can be attributed to the increase in mechanical activity resulting from the sum of the action potentials (APs) of the MUs with the increase of muscular force (Yoshitake et al., 2002) even in lower magnitudes (Akataki et al., 2003). This process occurs because of the redistribution of aqueous material present in the sarcoplasm (Neering et al., 1991), and because the mechanical signals generated from this process travel through the material between the muscle and the sensor (Dalton and Stokes, 1993).

The MMG signals originated in the skeletal muscle come from the mechanical vibrations generated by the muscular shocks of the APs (Yoshitake et al., 2002), which combined with MUs lead to MVC (tetany) (Neering et al., 1991; Seki et al., 2001). In this study, the thicker layers of body fat increased the distance
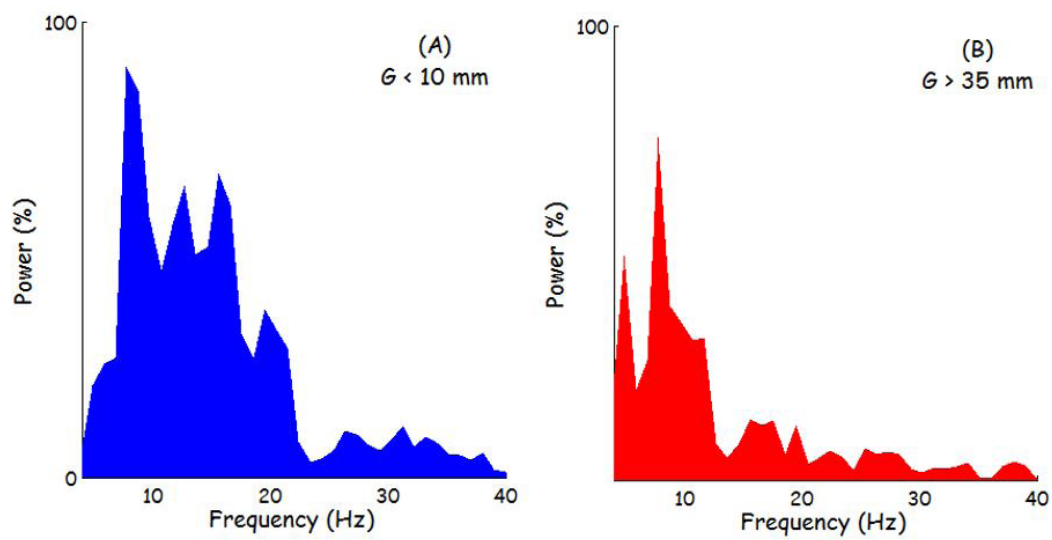

Figure 8. MMG $\mathrm{Z}$ axis signal of two representative participants of the groups $(\mathrm{G}<10$ and $\mathrm{G}>35)$, in which the spectral compression for the low frequencies for the group with thicker fat layers was observed $(\mathrm{G}>35)$. (A): $\mathrm{G}<10 \mathrm{~mm}, 15 \mathrm{~Hz}$ median frequency; (B): $\mathrm{G}>35 \mathrm{~mm}$, $10 \mathrm{~Hz}$ median frequency. 
between sensor and muscle, and the physical aspects of the fat acted as a low-pass filter, attenuating the MMG signal, as demonstrated by the analyzed parameters.

The use of MMG as indicator of the level of MUs firing rates, as well as indicator of increase of the action potentials (APs) originated from the skeletal muscle (Akataki et al., 2003), may be subject to attenuation in acquisition caused by thicker layers of subcutaneous fat. Therefore, it is important to consider the effects of fat when adopting MMG as a tool in applications such as prostheses control (Orizio et al., 2003), monitoring of muscular fatigue (Orizio et al., 2003; Scheeren et al., 2010; Tarata, 2003), neuromuscular diseases diagnosis ( $\mathrm{Hu}$ et al., 2007), respiratory muscle work (Sarlabous et al., 2014), among others. Subcutaneous fat, as demonstrated in this study, interferes on the analysis.

The results show that thicker layers of body fat act as a "low-pass filter" for the MMG signal. We observed attenuation of the MMG signals in all levels of rectus femoris muscle force production, indicating that, even in submaximal level of force, the MMG signals suffer attenuation according to the thickness of the subcutaneous fat layer. Moreover, during muscle fatigue processes, a decrease in the frequency of muscular mechanical vibration occurs, which may mislead MMG signal interpretation. As we wanted to assess the influence of ST on the MMG signal, we measure the ST exactly where the MMG sensor was positioned (muscle rectus femoris belly), but with this type of measurement it was not possible to estimate the percentage of body fat and the lean tissue mass, which is a limitation of this study.

We wanted to assess the influence of ST on the MMG signal, we measure the ST exactly where the MMG sensor was positioned (muscle rectus femoris belly), but with this type of measurement it was not possible to estimate the percentage of body fat and the lean tissue mass, which is a limitation of this study. As a perspective on future studies regarding MMG signal analysis, we suggest investigations to develop a way to implement a signal correction algorithm based on the subcutaneous fat layer/thickness.

\section{Acknowledgements}

We would like to thank CNPq, CAPES and SETI-PR for the essential funding and financial support.

\section{References}

Akataki K, Mita K, Itoh K, Suzuki N, Watakabe M. Acoustic and electrical activities during voluntary isometric contraction of biceps brachii muscles in patients with spastic cerebral palsy. Muscle \& Nerve. 1996; 19(10):1252-7.
PMid:8808650. http://dx.doi.org/10.1002/(SICI)10974598(199610)19:10<1252::AID-MUS2>3.0.CO;2-D.

Akataki K, Mita K, Watakabe M, Itoh K. Mechanomyogram and force relationship during voluntary isometric ramp contractions of the biceps brachii muscle. European Journal of Applied Physiology. 2001; 84(1-2):19-25. PMid:11394249. http://dx.doi.org/10.1007/s004210000321.

Akataki K, Mita K, Watakabe M, Itoh K. Mechanomyographic responses during voluntary ramp contractions of the human first dorsal interosseous muscle. European Journal of Applied Physiology. 2003; 89(6):520-5. PMid:12712352. http:// dx.doi.org/10.1007/s00421-003-0835-1.

Akataki K, Mita K, Watakabe M. Electromyographic and mechanomyographic estimation of motor unit activation strategy in voluntary force production. Electromyography and Clinical Neurophysiology. 2004; 44(8):489-96. PMid: 15646006

Alves N, Chau T. Stationarity distributions of mechanomyogram signals from isometric contractions of extrinsic hand muscles during functional grasping. Journal of Electromyography and Kinesiology. 2008; 18(3):509-15. PMid:17276085. http://dx.doi.org/10.1016/j.jelekin.2006.11.010.

Baars H, Jöllenbeck T, Humburg H, Schröder J. Surfaceelectromyography: skin and subcutaneous fat tissue attenuate amplitude and frequency parameters. Portland: ISBS; 2007. p. 1-4.

Baptista RR, Scheeren EM, Macintosh BR, Vaz MA. Lowfrequency fatigue at maximal and submaximal muscle contractions. Brazilian Journal of Medical and Biological Research. 2009; 42(4):380-5. PMid:19330267. http://dx.doi. org/10.1590/S0100-879X2009000400011.

Barkhaus PE, Nandedkar SD. Recording characteristics of the surface EMG electrodes. Muscle \& Nerve. 1994; 17(11):1317-23. PMid:7935554. http://dx.doi.org/10.1002/ mus. 880171111 .

Barry DT, Cole NM. Muscle sounds are emitted at the resonant frequencies of skeletal muscle. IEEE Transactions on Biomedical Engineering. 1990; 37(5):525-31. PMid:2345010. http://dx.doi.org/10.1109/10.55644.

Bassani E, Candotti C, Pasini M, Melo M, La Torre M. Avaliação da ativação neuromuscular em indivíduos com escoliose através da eletromiografia de superfície. Brazilian Journal of Physical Therapy. 2008; 12(1):13-9. http://dx.doi org/10.1590/S1413-35552008000100004.

Beck TW, Housh TJ, Johnson GO, Weir JP, Cramer JT, Coburn JW, Malek MH. Mechanomyographic and electromyographic time and frequency domain responses during submaximal to maximal isokinetic muscle actions of the biceps brachii. European Journal of Applied Physiology. 2004; 92(3):352-9. PMid:15106005. http://dx.doi.org/10.1007/s00421-004-1110-9.

Blemker SS, Delp SL. Rectus femoris and vastus intermedius fiber excursions predicted by three-dimensional muscle models. Journal of Biomechanics. 2006; 39(8):1383-91. PMid:15972213. http://dx.doi.org/10.1016/j.jbiomech.2005.04.012.

Cochrane KC, Housh TJ, Jenkins ND, Bergstrom HC, Smith CM, Hill EC, Johnson GO, Schmidt RJ, Cramer JT. Electromyographic, mechanomyographic, and metabolic 
responses during cycle ergometry at a constant rating of perceived exertion. Applied Physiology, Nutrition, and Metabolism. 2015; 40(11):1178-85. PMid:26481288. http:// dx.doi.org/10.1139/apnm-2015-0144.

Cooper MA, Herda TJ, Vardiman JP, Gallagher PM, Fry AC. Relationships between the mechanomyographic amplitude patterns of response and concentric isokinetic fatiguing tasks of the leg extensors. Physiological Measurement. 2013; 34(10):1293-301. PMid:24021893. http://dx.doi. org/10.1088/0967-3334/34/10/1293.

Cooper MA, Herda TJ, Vardiman JP, Gallagher PM, Fry AC. Relationships between skinfold thickness and electromyographic and mechanomyographic amplitude recorded during voluntary and non-voluntary muscle actions. Journal of Electromyography and Kinesiology. 2014; 24(2):207-13. PMid:24444832. http://dx.doi.org/10.1016/j. jelekin.2013.12.005.

Cooper MA, Herda TJ. Muscle-related differences in mechanomyography: force relationships are model-dependent. Muscle \& Nerve. 2014; 49(2):202-8. PMid:23649718. http:// dx.doi.org/10.1002/mus.23896.

Correa CS, Silva BGC, Alberton CL, Wilhelm EN, Moraes AC, Lima CS, Pinto RS. Analysis of maximal isometric force and EMG signal in lower limb exercise. Revista Brasileira de Cineantropometria \& Desempenho Humano. 2011; 13(6):429-35.

Cramer JT, Housh TJ, Johnson GO, Ebersole KT, Perry SR, Bull AJ. Mechanomyographic amplitude and mean power output during maximal, concentric, isokinetic muscle actions. Muscle \& Nerve. 2000; 23(12):1826-31. PMid:11102905. http:/ dx.doi.org/10.1002/1097-4598(200012)23:12<1826::AIDMUS5>3.0.CO;2-7.

Dalton PA, Stokes MJ. Frequency of acoustic myography during isometric contraction of fresh and fatigued muscle and during dynamic contractions. Muscle \& Nerve. 1993; 16(3):255-61. PMid:8446123. http://dx.doi.org/10.1002/ mus.880160303.

Gonçalves M, Barbosa FSS. Análise de parâmetros de força e resistência dos músculos eretores da espinha lombar durante a realização de exercício isométrico em diferentes níveis de esforço. Revista Brasileira de Medicina do Esporte. 2005; 11(2):109-14. http://dx.doi.org/10.1590/ S1517-86922005000200003.

Herda TJ, Cooper MA. Muscle-related differences in mechanomyography frequency-force relationships are model dependent. Medical \& Biological Engineering \& Computing. 2015; 53(8):1-9. PMid:25805064. http://dx.doi. org/10.1007/s11517-015-1261-3.

Herda TJ, Housh TJ, Fry AC, Weir JP, Schilling BK, Ryan ED, Cramer JT. A noninvasive, log-transform method for fiber type discrimination using mechanomyography. Journal of Electromyography and Kinesiology. 2010; 20(5):787-94. PMid:20172740. http://dx.doi.org/10.1016/j. jelekin.2010.01.004.

Herda TJ, Walter AA, Costa PB, Ryan ED, Stout JR, Cramer JT. Differences in the log-transformed electromyographicforce relationships of the plantar flexors between high-and moderate-activated subjects. Journal of Electromyography and Kinesiology. 2011;21(5):841-6. PMid:21737308. http:// dx.doi.org/10.1016/j.jelekin.2011.05.008.

Hu X, Tong K, Li L. The mechanomyography of persons after stroke during isometric voluntary contractions. Journal of Electromyography and Kinesiology. 2007; 17(4):473-83. PMid:16603386. http://dx.doi.org/10.1016/j. jelekin.2006.01.015.

Jaskólska A, Brzenczek W, Kisiel-Sajewicz K, Kawczyński A, Marusiak J, Jaskólski A. The effect of skinfold on frequency of human muscle mechanomyogram. Journal of Electromyography and Kinesiology. 2003; 14(2):217-25. PMid:14962774. http://dx.doi.org/10.1016/j.jelekin.2003.08.001.

Kemp B, Olivan J. European data format 'plus'(EDF+), an EDF alike standard format for the exchange of physiological data. Clinical Neurophysiology. 2003; 114(9):1755-61. PMid:12948806. http://dx.doi.org/10.1016/S13882457(03)00123-8.

Krueger E, Scheeren EM, Nogueira-Neto GN, Button VLSN, Nohama P. Correlation between spectral and temporal mechanomyography features during functional electrical stimulation. Research on Biomedical Engineering. 2016; 32(1):85-91. http://dx.doi.org/10.1590/2446-4740.02315.

Krueger E, Scheeren EM, Nogueira-Neto GN, Neves EB, Button VLS, Nohama P. Influence of skinfold thickness in mechanomyography features. In: World Congress on Medical Physics and Biomedical Engineering; 2013 May 26-31; Beijing, China. Heidelberg: Springer; 2013. p. 2030-3.

Madeleine P, Bajaj P, Søgaard K, Arendt-Nielsen L. Mechanomyography and electromyography force relationships during concentric, isometric and eccentric contractions. Journal of Electromyography and Kinesiology. 2001; 11(2):113-21. PMid:11228424. http://dx.doi.org/10.1016/ S1050-6411(00)00044-4.

Malek MH, Coburn JW. The utility of electromyography and mechanomyography for assessing neuromuscular function: a noninvasive approach. Physical Medicine and Rehabilitation Clinics of North America. 2012; 23(1):2332, ix. PMid:22239871. http://dx.doi.org/10.1016/j. pmr.2011.11.005.

Marusiak J, Jaskólska A, Kisiel-Sajewicz K, Yue GH, Jaskólski A. EMG and MMG activities of agonist and antagonist muscles in Parkinson's disease patients during absolute submaximal load holding. Journal of Electromyography and Kinesiology. 2009; 19(5):903-14. PMid:18456512. http://dx.doi.org/10.1016/j.jelekin.2008.03.003.

Matta TT, Perini TA, Oliveira GL, Ornellas JS, Louzada AA, Magalhães J, Imbiriba LA, Garcia MAC. Interpretação dos mecanismos de gradação da força muscular através da acelerometria. Revista Brasileira de Medicina do Esporte. 2005; 11(5):306-10. http://dx.doi.org/10.1590/S151786922005000500012 .

Neering I, Quesenberry L, Morris V, Taylor S. Nonuniform volume changes during muscle contraction. Biophysical Journal. 1991; 59(4):926-33. PMid:2065192. http://dx.doi. org/10.1016/S0006-3495(91)82306-2. 
Nogueira-Neto GN, Scheeren EM, Krueger E, Nohama P, Button VLSN. The influence of window length analysis on the time and frequency domain of mechanomyographic and electromyographic signals of submaximal fatiguing contractions. Open Journal of Biophysics. 2013; 3(3): 17890. http://dx.doi.org/10.4236/ojbiphy.2013.33021.

Nogueira-Neto GN, Scheeren EM, Nohama P, Button VLS. Triaxial mechanomyography of the Biceps Brachii muscle during sustained submaximal isometric contractions. In: World Congress on Medical Physics and Biomedical Engineering; 2009 Sept 7-12; Munich, Germany. Heidelberg: Spring; 2010. p. $1502-5$.

Orizio C, Gobbo M, Diemont B, Esposito F, Veicsteinas A. The surface mechanomyogram as a tool to describe the influence of fatigue on biceps brachii motor unit activation strategy: historical basis and novel evidence. European Journal of Applied Physiology. 2003; 90(3-4):326-36. PMid:12923643. http://dx.doi.org/10.1007/s00421-003-0924-1.

Orizio C, Perini R, Veicsteinas A. Muscular sound and force relationship during isometric contraction in man. European Journal of Applied Physiology. 1989; 58(5):52833. PMid:2759079. http://dx.doi.org/10.1007/BF02330708.

Orizio C. Muscle sound: bases for the introduction of a mechanomyographic signal in muscle studies. Critical Reviews in Biomedical Engineering. 1992; 21(3):201-43. PMid:8243092.

Perry SR, Housh TJ, Weir JP, Johnson GO, Bull AJ, Ebersole KT. Mean power frequency and amplitude of the mechanomyographic and electromyographic signals during incremental cycle ergometry. Journal of Electromyography and Kinesiology. 2001; 11(4):299-305. PMid:11532601. http://dx.doi.org/10.1016/S1050-6411(00)00057-2.

Polato D, Carvalho MC, Garcia MAC. Efeitos de dois parâmetros antropométricos no comportamento do sinal mecanomiográfico em testes de força muscular. Revista Brasileira de Medicina do Esporte. 2008; 14(3):221-6. http://dx.doi.org/10.1590/S1517-86922008000300012.

Sarlabous L, Torres A, Fiz JA, Jané R. Evidence towards improved estimation of respiratory muscle effort from diaphragm mechanomyographic signals with cardiac vibration interference using sample entropy with fixed tolerance values. PLoS One. 2014; 9(2):e88902. PMid:24586436. http://dx.doi.org/10.1371/journal.pone.0088902.
Scheeren EM, Krueger-Beck E, Nogueira-Neto GN, Nohama P, Button V. Wrist movement characterization by mechanomyography technique. Journal of Medical and Biological Engineering. 2010; 30(6):373-80. http://dx.doi. org/10.5405/jmbe.757.

Seki K, Taniguchi Y, Narusawa M. Alterations in contractile properties of human skeletal muscle induced by joint immobilization. The Journal of Physiology. 2001; 530(3):52132. PMid:11158281. http://dx.doi.org/10.1111/j.14697793.2001.0521k.x.

Shin I, Ahn S, Choi E, Ryu J, Park S, Son J, Kim Y. Fatigue analysis of the quadriceps femoris muscle based on mechanomyography. International Journal of Precision Engineering and Manufacturing. 2016; 17(4):473-8. http:// dx.doi.org/10.1007/s12541-016-0059-z.

Tarata MT. Mechanomyography versus electromyography, in monitoring the muscular fatigue. Biomedical Engineering Online. 2003; 2(3):3. PMid:12625837. http://dx.doi. org/10.1186/1475-925X-2-3.

Trevino MA, Herda TJ. Mechanomyographic mean power frequency during an isometric trapezoid muscle action at multiple contraction intensities. Physiological Measurement. 2015; 36(7):1383-97. PMid:26015456. http://dx.doi. org/10.1088/0967-3334/36/7/1383.

Vaz MA, Herzog W. A mecanomiografia como técnica nãoinvasiva para o estudo da função muscular. Movimento. 1999; 5(10):15-20.

Yoshitake Y, Shinohara M, Ue H, Moritani T. Characteristics of surface mechanomyogram are dependent on development of fusion of motor units in humans. Journal of Applied Physiology. 2002; 93(5):1744-52. PMid:12381762. http:// dx.doi.org/10.1152/japplphysiol.00008.2002.

Youn W, Kim J. Estimation of elbow flexion force during isometric muscle contraction from mechanomyography and electromyography. Medical \& Biological Engineering \& Computing. 2010; 48(11):1149-57. PMid:20524072. http:// dx.doi.org/10.1007/s11517-010-0641-y.

Zuniga JM, Housh TJ, Camic CL, Hendrix CR, Schmidt RJ, Mielke M, Johnson GO. A mechanomyographic fatigue threshold test for cycling. International Journal of Sports Medicine. 2010; 31(09):636-43. PMid:20589588. http:// dx.doi.org/10.1055/s-0030-1255112.

\title{
Authors
}

\author{
Eduardo Mendonça Scheeren ${ }^{1 *}$, Lindomar Mineiro', Eduardo Borba Neves ${ }^{2}$, Eddy Krueger ${ }^{2,3}$, \\ Guilherme Nunes Nogueira Neto ${ }^{4}$, Percy Nohama ${ }^{1,5}$ \\ ${ }^{1}$ Graduation Program in Health Technology, Pontifícia Universidade Católica do Paraná - PUC-PR, Rua Imaculada \\ Conceição, 1155, Bloco verde, $2^{\circ}$ andar, Prado Velho, CEP 80215-901, Curitiba, PR, Brazil.
}

${ }^{2}$ Programa de Pós-graduação em Engenharia Biomédica, Universidade Tecnológica Federal do Paraná - UTFPR, Curitiba, PR, Brazil.

${ }^{3}$ Programa de Pós-graduação Associado UEL-UNOPAR em Ciências da Reabilitação, Universidade Estadual de Londrina - UEL, Londrina, PR, Brazil.

${ }^{4}$ Computer Engineering Department, Pontifícia Universidade Católica do Paraná - PUC-PR, Curitiba, PR, Brazil.

${ }^{5}$ Programa de Pós-graduação em Engenharia Elétrica e Informática Industrial, Universidade Tecnológica Federal do Paraná - UTFPR, Curitiba, PR, Brazil. 